\title{
Point Prevalence, Risk Factors and Useful Parameters for Food Allergy in Children with Atopic Dermatitis
}

\author{
Atopik Dermatitli Çocuklardaki Besin Alerjisini Tahminde \\ Kullanılabilecek Parametreler ve Risk Faktörleri, Nokta Prevalans
}

\section{Nazlı ERCAN}

University of Health Sciences, Gulhane Research and Training Hospital, Department of Pediatrics, Division of Pediatric Allergy and Immunology, Ankara

\begin{abstract}
$\ddot{\mathbf{O} z}$
Atopik dermatit'li çocuklarda besin alerjisi varlığı ve yaygınlığı konusunda fikir birliğine varılamamıştır. Çalışmamızda, okul öncesi çocuklarda atopik dermatit'e eşlik eden besin alerjisi insidansını araștırmak ve bu ilișkiyi tahmin etmede kullanılabilecek parametreleri belirlemeyi amaçladık. Bu vakakontrol çalışması, üniversite hastanemizde 2017-2020 yılları arasında SCORAD indeksi $>15$ olan, 0-6 yaş arası AD'li toplam 401 çocuğun retrospektif bir incelemesidir. Araştırmaya dahil edilen çocukların sosyodemografik özellikleri ve alerji testleri incelenmiştir. Atopik dermatit'in başlangıç yaşına göre çocuklar iki alt gruba ayrılmıștır. (Alt grup I: $<24$ ay, Alt grup II: $\geq 24$ ay). Atopik dermatit'li hastaların en az bir yiyeceğe karşı besin alerjisi prevalansı \%23.6 $(\mathrm{n}=95)$ idi. Cinsiyet, çocuğun yaşı, atopik dermatit başlangıç yaşı ve kan eozinofil sayısındaki (KES) artış bağımsız risk faktörleri olarak saptandı. (p-değerleri sırasıyla; $0.047,0.004,0.014$ ve 0.012 ). Tamamlayıcı beslenmeye başlama zamanı, akrabalık derecesi ve serum süt spesifik IgE pozitifliği alt grup I için bağımsız risk faktörleriydi (p-değerleri sırasıyla; $0.045,0.187,0.019)$. Alt grup I'deki besin alerjisini tahmin etmede KES için kesme noktası $525 \mathrm{~K} / \mathrm{mm} 3$ ve KES/WBC oranı 0.0522 idi (duyarlılık \%73.91; özgüllük \%63.64). Araştırmamızda belirlenen risk faktörleri ve in-vitro parametreler klinisyenlere AD'li çocuklarda eşlik eden besin alerjisini tahmin etmede yol gösterici olabilir.

Anahtar Kelimeler: Atopik Dermatit, Besin Alerjisi, Kan
\end{abstract} Eozinofil Sayısı, Okul Öncesi Çocuklar

\section{Introduction}

Atopic dermatitis (AD) is a chronic, itchy inflammatory skin disease that is common in children. AD may represent the initial stage of the concept defined as "Atopic March", which expresses the natural course of the allergic disease sequence in childhood (1). AD, usually associated with the development of immunoglobulin E (IgE) antibodies to food allergens in the early infantile period, may also be associated with food allergy (FA) symptoms (2).

In $\mathrm{AD}$, a food sensitivity can be seen not only as Ig E-mediated hypersensitivity but also as delayed cell-mediated hypersensitivity. In addition to the similarity of the onset times, FA and AD may also

\begin{tabular}{|c|c|}
\hline Nazlı ERCAN & $\begin{array}{l}\text { ORCID No } \\
0000-0003-3216-8775\end{array}$ \\
\hline Başvuru Tarihi / Received: & 25.08 .2020 \\
\hline Kabul Tarihi / Accepted : & 23.01 .2021 \\
\hline Adres / Correspondence : & Nazlı ERCAN \\
\hline $\begin{array}{l}\text { University of Health Sciences, } \\
\text { Hospital, Department of Pediatr } \\
\text { and Immunology, Ankara }\end{array}$ & $\begin{array}{l}\text { Gulhane Research and Training } \\
\text { ics, Division of Pediatric Allergy }\end{array}$ \\
\hline e-posta / e-mail : & drnazliercan@gmail.com \\
\hline
\end{tabular}

\begin{abstract}
No consensus has yet been reached on the presence and prevalence of food allergy (FA) in children with atopic dermatitis (AD). To investigate the incidence of FA accompanying $\mathrm{AD}$ in preschool children and to determine the parameters that can be used to predict this association. This case-control study is a retrospective analysis of 401 children aged 0-6 years with AD who had a SCORAD index of $>15$ between 2017-2020 at our university hospital. Children were subgrouped regarding the age of onset of AD (subgroup I: <24 months, subgroup II: $\geq 24$ months). The sociodemographic characteristics and allergological test results were studied. Food allergy prevalence of patients with $\mathrm{AD}$ to at least one food was $23.6 \%(n=95)$. Gender, age of the child, and age of onset of AD increase in BEC were the independent risk factors ( $\mathrm{p}=0.047 ; 0.004$; 0.014 and $\mathrm{p}=0.012$, respectively). Time to start complementary feeding, degree of kinship, and serum specific IgE milk positivity were independent risk factors for study subgroup I ( $p=0.045,0.187$, 0.019 , respectively). In predicting FA in subgroup $\mathrm{I}$, the cut-off point for $\mathrm{BEC}$ was $525 \mathrm{~K} / \mathrm{mm} 3$, and the $\mathrm{BEC} / \mathrm{WBC}$ ratio was 0.0522 (73.91\% sensitivity, $63.64 \%$ specificity). The risk factors and in-vitro parameters determined can guide physicians in predicting the concomitant FA in children with $\mathrm{AD}$.
\end{abstract}

Keywords: Atopic Dermatitis, Blood Eosinophil Count, Food Allergy, Preschool Children

be linked to a causal relationship (3). Besides, deviation in the immune response takes place in both FA and AD. The genetic component is essential in immune deviation, and it has been suggested that the increase in $\mathrm{AD}$ and FA in the last decade may be due to epigenomic changes, mainly driven by environmental exposure $(4,5)$.

Three different reaction types to food in $\mathrm{AD}$ were defined (6,7). Firstly, non-eczematous reactions such as urticaria, erythema, and pruritus. These are early or immediate-type reactions, Ig-E mediated, usually occurring within the first hour, and may be accompanied by non-cutaneous respiratory or gastrointestinal symptoms or even anaphylaxis. Secondly, there are isolated eczematous reactions with exacerbation of eczema. These are late or delayed-type reactions and are non-Ig E mediated, usually occurring 2-6 hours or days after suspected food intake. Delayed-type reactions can be T cellmediated or IgE independent reactions to food (8). The mixed type is a combination of eczematous and non-eczematous reactions. Studies to date have shown that the prevalence of FA in AD may vary depending on the severity of $\mathrm{AD}$, the age group tested, the referenced center (primary and referral 
center), race, and geographic region. Many studies from high-income countries have shown that children with moderate and severe AD have a sensitivity of about $60 \%$ to common foods and about $30-40 \%$ of FA associated with food provocation (913).

The aim of this study was to investigate the incidence of FA proven with OFC accompanying $\mathrm{AD}$ in preschool children and the parameters that can be used to predict this association.

\section{Material and Method}

Our pediatric department is a tertiary care center serving a population of nearly 6 million people. Pediatric allergy and immunology unit usually receive patients from general pediatricians, dermatologists, and general practitioners due to confirmation of initial diagnosis, allergological evaluation, and to receive specialist advice for children with AD. The study was approved by our University Hospital's Ethical Committee (Project/Decision no: 19/412; Meeting no: 2019/18). A total of 401 children, 0-6 years of age, with a diagnosis of $\mathrm{AD}$ were analyzed from the hospital's database in years between 2017-2020, retrospectively. The diagnosis of $\mathrm{AD}$ was made according to the criteria of Hanifin and Rajka. All families gave agreement to the consent form of allergological assessment of their children.

The severity of $\mathrm{AD}$ was evaluated with the SCORAD (Scoring Atopic Dermatitis) index, and children with SCORAD index $>15$ were included. The exclusion criteria were children who had the diagnosis of asthma, allergic rhinitis, food-induced enteropathy, enterocolitis and/or proctocolitis, and any allergic eosinophilic gastrointestinal disease other than AD. Moreover, children with a history of acute infection and need for systemic, topical or inhaled corticosteroid, montelukast, immunosuppressive, and/or antibiotic use in the last 3 months were not enrolled in the study.

The sociodemographic parameters and allergy histories of children were recorded. Animal contact status was defined as contact with an animal at least several times within one month. Frequent infection evaluation was made according to the ten stimulating signs for primary immunodeficiency, represented by the Jeffrey Modell Foundation. Any missing information was completed with a phone call to families.

All laboratory findings of $\mathrm{AD}$ patients at the time of diagnosis were studied including, Wbc $(\mathrm{K} / \mathrm{mm} 3)$, blood eosinophil count (BEC) $(\mathrm{K} / \mathrm{mm} 3)$ (performed with Beckman Coulter LH 780), total IgE, milk, casein, egg, and wheat flour specific $\operatorname{IgE}(\mathrm{kU} / \mathrm{L})$ levels, skin prick test (SPT), and hospital-based open oral food challenge test (OFC) results.

Serum total IgE and food-specific serum $\mathrm{IgE}$ levels were measured using the CAP System fluorescence-enzyme immunoassay (CAP limit of the assay $0.35 \mathrm{KUA} / \mathrm{L}$, Pharmacia Diagnostics, Uppsala Sweden). Food-specific $\operatorname{IgE}$ level $\geq 0.35$ KUA/L were considered positive. Food specific IgE selection was determined according to the patient's history and/or SPT results.

SPT was done with the aeroallergens recommended in Global Allergy and Asthma European Network position paper with the same methodology (14). Concerning the food allergens milk, egg yolk, and white, wheat flour, potatoes, green lentils, red lentils, peanuts, hazelnuts, walnuts, almonds, and soy (Allergopharma, Reinbek, Germany) were used. Modified SPT was performed for milk and egg by using raw egg white, yolk, and $2 \%$ drops of daily milk. If the initial SPT results were incompatible with the patient's history and clinical status, SPT was performed with additional food antigens.

Food selection was made for the open OFC test based on a history of hypersensitivity to food and SPT and/or food-specific IgE results. Although the allergometric tests were negative, the OFC test was performed with a suspicious food, if there was a history of hypersensitivity to nourishment. If the patient's history and food-specific IgE and/or SPT results were negative, the OFC test was not performed (Figure 1).

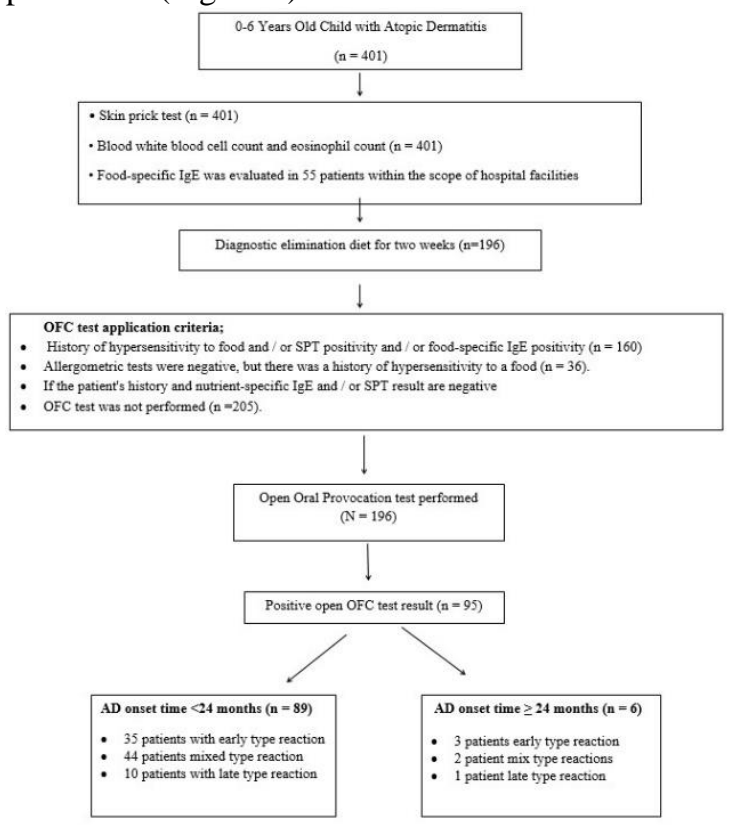

Figure 1. Study flow chart built upon hospital protocol.

All forms of suspected nutrients were removed from the patient's diet at least two weeks before the OFC test. In case of exacerbation of AD during the elimination diet, patients were asked to refer to the hospital. OFC test was performed when the skin lesions were under optimal control, in 7 to 14 days after discontinuation of all medications. If the child is sensitive to more than one food, OFC has performed for each nutrient at least one week apart on different days. 
The initial oral provocation doses were determined based on the type of food, the patient's history, and the expected reactions. Provocation doses were gradually increased (max: 6 doses) until they reached the required daily intake for the age. Oral provocation test intervals were $15 \mathrm{~min}$ if $\mathrm{IgE}$ mediated food sensitivity was suspected, and $45 \mathrm{~min}$ if non-Ig E-mediated food sensitivity was suspected. The criteria used to determine the outcome of food provocation included only signs and symptoms that had just begun objectively (15). Positive OFC results were divided into early, late/delayed and mixed reactions.

The patients were observed for 2-4 hours after a positive OFC and at least 2 hours after a negative test. Families were phoned $48-72$ hours after OFC to question child's well-being and late symptoms. The diagnosis of FA was made as an early and/or late reaction to at least one food in the open-controlled OFC test.

The clinical phenotype of the enrolled children was determined according to the age of onset of $\mathrm{AD}$ (16), as subgroup I (very early-onset; <24 months) and subgroup II (early-onset; $\geq 24$ months). The quantitative parameters and risk factors that can be used to predict FA that may accompany during the diagnosis of AD were investigated. Secondly, the change of these parameters between subgroups were examined.

Data were analyzed with IBM SPSS V23. The Shapiro Wilk test examined compliance with a normal distribution. Independent samples t-test was used to compare the normal distribution of the data according to additional allergic disease. The double logistic regression analysis method was used to determine independent risk factors affecting the additional allergic disease. Analysis results were presented as percentages for the frequency of categorical data and as mean standard deviation, minimum, and maximum values for quantitative data. Logistic regression analysis results were expressed as OR $(95 \% \mathrm{CI})$. The significance level was taken as $\mathrm{p}<0.05$. Cut-off values according to FA were examined by ROC analysis, and the results were presented as AUC, Sensitivity, Specificity, PPV, NPV, and Accuracy.

\section{Results}

The mean $( \pm \mathrm{SD})$ age of 401 Caucasian origin children was $41.27 \pm 11.04$ months. Of those, $28.9 \%$ were female $(n=116)$ and $71 \%(n=85)$ were male. The demographic parameters of children are summarized in Table 1 . The onset age of symptoms of $\mathrm{AD}$ was $14.93 \pm 22.79$ months, the time length of breastfeeding of $\mathrm{AD}$ infants was $11.43 \pm 5.35$, and the start of complementary foods to infants of $\mathrm{AD}$ was $6.78 \pm 1.37$ months.

Table 1. Sociodemographic characteristics of preschool children with atopic dermatitis.

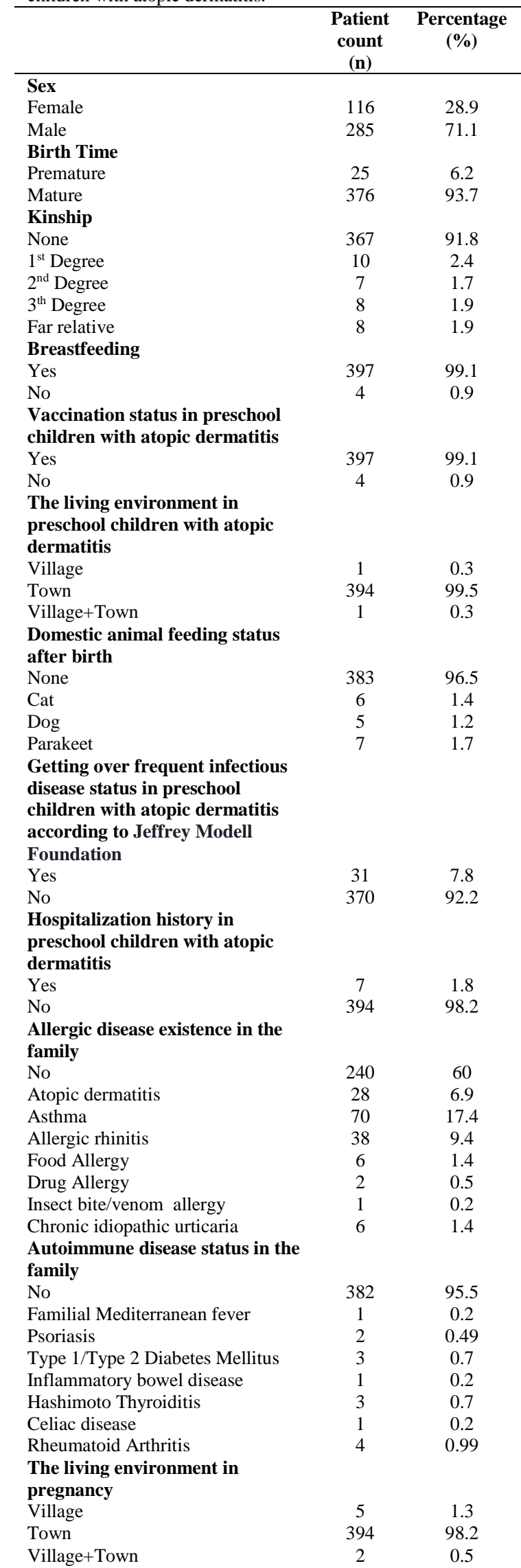


Animal contact status in

\begin{tabular}{lcc} 
pregnancy & & \\
No & 386 & 96.2 \\
Cat & 5 & 1.2 \\
Dog & 4 & 0.9 \\
Parakeet & 6 & 1.4 \\
How long has the mother been in & & \\
contact with the animal during & & \\
pregnancy? & 386 & \\
No & 7 & 1.7 \\
$1^{\text {st }}$ trimester & 5 & 1.2 \\
$2^{\text {nd }}$ trimester & 1 & 0.2 \\
$3^{\text {th }}$ trimester & 2 & 0.5 \\
Throughout pregnancy & & \\
\hline
\end{tabular}

The laboratory data of AD children are presented in Supp. Table 1. In 55 patients (13.7\%), at least one food-specific $\mathrm{IgE}$ value was examined. Serum specific IgE positivity of patients $(\geq 0.35 \mathrm{KUA} / \mathrm{L})$ were against to milk in $65.4 \% \quad(n=36)$, casein in $36.3 \%(n=20)$, egg in $41.8 \%(n=23)$ and $3.6 \%(n=2)$ in wheat flour.

SPT was positive in $39.9 \%(n=60)$ of 401 AD patients, with sensitivity to at least one food in SPT $(\mathrm{n}=153 ; 37.4 \%)$. SPT showed the highest sensitivity to egg $(n=9 ; 9.7 \%)$ (Table 2). OFC test was performed to $196(48.8 \%)$ patients with suspicion of FA. In the hospital-based OFC tests of AD patients (23.6\%; $n=95) ; 38$ had early, 11 had late and 46 had mixed type reactions against at least one food. 6 patients with positive OFC tests had an AD onset time $\geq 24$ months; 3 early-type (one in egg white, one in cow's milk and one in multi-food), 2 mixed types (one in egg, one in multi-food) and one late-type (egg white) reaction. The highest positivity in OFC was with egg white in 37 patients, secondly with milk in 28 patients, and at least two foods in 16 patients.

Table 2. Skin prick test and food provocation test results of preschool children with atopic dermatitis.

\begin{tabular}{|c|c|c|}
\hline & $\begin{array}{l}\text { Patient } \\
\text { count } \\
\text { (n) }\end{array}$ & $\begin{array}{c}\text { Percent } \\
(\%)\end{array}$ \\
\hline \multicolumn{3}{|l|}{ Skin Prick Test } \\
\hline Positive & 160 & 39.9 \\
\hline Negative & 241 & 60.1 \\
\hline Total & 401 & \\
\hline \multicolumn{3}{|l|}{ Skin test Positivity Results } \\
\hline Milk & 17 & 4.2 \\
\hline Egg yolk & 10 & 2.4 \\
\hline Egg whites & 8 & 1.9 \\
\hline Egg yolk+Egg whites (Egg) & 39 & 9.7 \\
\hline Wheat flour & 8 & 1.9 \\
\hline Soy & 3 & 0.7 \\
\hline Potato & 8 & 1.9 \\
\hline Hazelnut & 3 & 0.7 \\
\hline Multiple nuts & 1 & 0.2 \\
\hline Multiple foods & 50 & 12.4 \\
\hline \multicolumn{3}{|c|}{$\begin{array}{l}\text { Domestic inhaled allergens (house } \\
\text { dust, mold,. animal epithelium, } \\
\text { cockroaches) }\end{array}$} \\
\hline $\begin{array}{l}\text { Out-of-home inhaler allergens } \\
\text { (pollen) }\end{array}$ & 3 & 0.7 \\
\hline Home/outdoor inhaler & 7 & 1.7 \\
\hline allergens+Food allergens & 3 & 0.7 \\
\hline \multicolumn{3}{|l|}{ Food provocation results } \\
\hline Positive & 95 & 23.6 \\
\hline Negative & 101 & 25.2 \\
\hline Total & 196 & 48.8 \\
\hline
\end{tabular}

According to the presence of FA accompanying $\mathrm{AD}$, only serum total $\mathrm{IgE}$ mean values were significantly different $(p=0.002)$. The mean value of FA was 144.7, while the mean value was 62 for those without FA (Table 3).

The risk factors associated with $\mathrm{AD}$, which may affect the presence of FA, were examined by dual logistic regression analysis (Table 4). The gender, age of the child, and age of onset of AD were found to be independent risk factors socio demographically $(\mathrm{p}=0.047,0.004$ and 0.014 , respectively). As a laboratory parameter, increased BEC has been identified as an independent risk factor on the presence of FA in AD patients, and increases the risk of the existence of FA by 1001 times $(p=0.012)$.

In subgroup analysis time to start complementary feeding, degree of kinship and serum specific $\operatorname{IgE}$ milk positivity were independent risk factors for study subgroup I $(\mathrm{n}=334), \quad[\mathrm{p}=0.045$, OR $(95 \%$ $\mathrm{CI})=0.444 \quad(0.201-981) ; \quad \mathrm{p}=0.187, \quad$ OR $\quad(95 \%$ $\mathrm{CI})=0.187 \quad(0.05-0.693) ; \quad \mathrm{p}=0.019, \quad$ OR $\quad(95 \%$ $\mathrm{CI})=0.012(0-0.478)$, respectively]. In subgroup II $(n=67)$, serum total $\operatorname{IgE}$ and specific $\operatorname{IgE}$ egg positivity were the independent risk factors [p=0.042, OR (95\% CI $=1.005$ (1-1.01); $\mathrm{p}=0.042$, OR $(95 \% \mathrm{CI})=0.169(0.031-0.934)$, respectively]. The cut-off point for BEC was $525 \mathrm{~K} / \mathrm{mm} 3$ in study subgroup II in predicting the presence of concomitant FA. The significant cut-off value for BEC/WBCs ratio was 0.0522 (Figure 2A, Supplemental Table 2). Serum total Ig E level above $26.85 \mathrm{kU} / \mathrm{L}$ was significant for FA concomitant with AD in study subgroup II (Figure 2B, Supplemental Table 2).

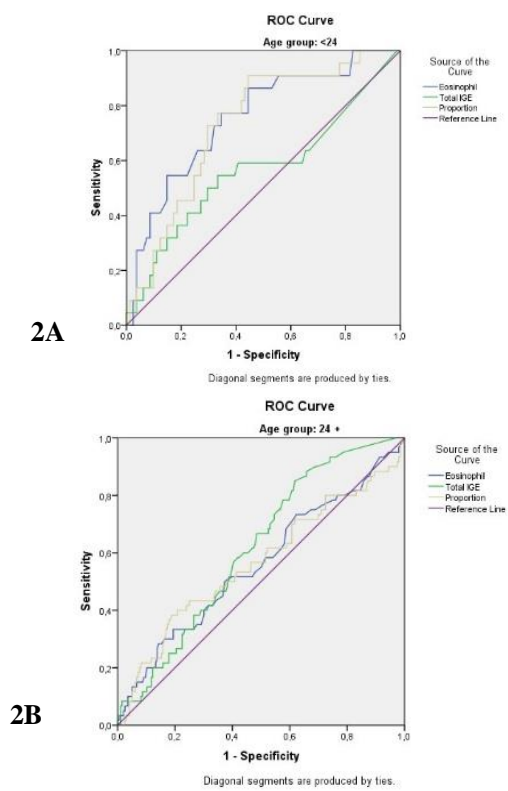

Figure 2. 2A, and 2B. The eosinophil count, Total Ig E value and Eosinophil count / White blood cell count ratio for the presence of concomitant food allergy in preschool children with atopic dermatitis (subgroups I and II). 
Table 3. Comparison of quantitative data according to the presence of food allergy in preschool children with atopic dermatitis

\begin{tabular}{|c|c|c|c|c|c|c|c|c|c|}
\hline & \multicolumn{4}{|c|}{ Negative Food Allergy } & \multicolumn{4}{|c|}{ Positive Food Allergy } & \multirow[t]{2}{*}{$\begin{array}{c}\mathbf{p} \\
\text { value }\end{array}$} \\
\hline & Median & S.Deviation & Minimum & Maximum & Median & S.Deviation & Minimum & Maximum & \\
\hline $\begin{array}{l}\text { WBC } \\
\left(\mathbf{K} / \mathbf{m m}^{3}\right)\end{array}$ & 10226.5 & 7660.2 & 950.0 & 120000.0 & 10137.2 & 2996.7 & 4400.0 & 22100.0 & 0.900 \\
\hline $\begin{array}{l}\text { Eosinophil count } \\
\left(\mathrm{K} / \mathbf{m m}^{3}\right)\end{array}$ & 477.1 & 554.0 & 20.0 & 5200.0 & 568.6 & 506.1 & 1.0 & 2920.0 & 0.121 \\
\hline $\begin{array}{l}\text { Eosinophils count / } \\
\text { WBC ratio }\end{array}$ & 0.048 & 0.045 & 0.0026 & 0.368 & 0.054 & 0.039 & 0.0001 & 0.182 & 0.176 \\
\hline $\begin{array}{l}\text { Total Ig E } \\
(\mathbf{k U / L )}\end{array}$ & 62.0 & 163.7 & 1.0 & 1931.0 & 144.7 & 351.3 & 3.8 & 3010.0 & 0.002 \\
\hline
\end{tabular}

Table 4. Logistic regression of independent risk factors affecting the presence of food allergy in preschool children with atopic dermatitis.

\begin{tabular}{|c|c|c|}
\hline \multirow[b]{2}{*}{$\begin{array}{l}\text { Sociodemographic Characteristics of Preschool Children with Atopic } \\
\text { Dermatitis }\end{array}$} & \multicolumn{2}{|c|}{ Multivariate (Enter Metodu) } \\
\hline & OR (\%95 CI $)$ & p-value \\
\hline Sex (male) & $2.112(1.009-4.419)$ & 0.047 \\
\hline Age (month) & $1.0288(1.009-1.047)$ & 0.004 \\
\hline Age of onset of atopic dermatitis (months) & $0.967(0.942-0.993)$ & 0.014 \\
\hline Birth time & $0.558(0.182-1.706)$ & 0.306 \\
\hline Time to take breast milk of the child & $1.018(0.967-1.072)$ & 0.493 \\
\hline Supplement food starting time of child & $0.877(0.682-1.127$ & 0.305 \\
\hline Degree of kinship between parents (Mother and Father) & $0.698(0.231-2.104)$ & 0.523 \\
\hline Vaccination Status of Child & $2.101(0.361-12.219)$ & 0.408 \\
\hline Getting over frequent infectious disease status of child & $0.47(0.148-1.493)$ & 0.200 \\
\hline Hospitilazation status of the child & $0.58(0.066-5.105)$ & 0.623 \\
\hline Atopic disease existence status of family & $0.917(0.47-1.79)$ & 0.800 \\
\hline Autoimmun disease existence status of family & $0.821(0.234-2.881)$ & 0.758 \\
\hline \multicolumn{3}{|l|}{ Laboratory Parameters of pre-school children with atopic dermatitis } \\
\hline WBC & $1(1-1)$ & 0.685 \\
\hline Eosinophils count & $1.001(1-1.002)$ & 0.012 \\
\hline Total Ig E Level & $1.001(0.999-1.004)$ & 0.267 \\
\hline Spesific Ig E Milk & $0.58(0.242-1.386)$ & 0.220 \\
\hline Spesific Ig E Casein & $1.829(0.772-4.33)$ & 0.170 \\
\hline Spesific Ig E Egg & $0.731(0.259-2.061)$ & 0.554 \\
\hline Spesific Ig E Wheat flour & $0.319(0.071-1.431)$ & 0.136 \\
\hline Determining Positivity in the skin prick test & $0.504(0.141-1.805)$ & 0.293 \\
\hline
\end{tabular}

\begin{tabular}{lcccc}
\multicolumn{5}{c}{ Supplemental Table 1. Laboratory values of preschool children with atopic dermatitis. } \\
\hline & Patient count $(\mathbf{N})$ & Median \pm SD & Minimum & Maximum \\
\hline WBC $\left(\mathbf{K} / \mathbf{m m}^{\mathbf{3}}\right)$ & $\mathbf{4 0 1}$ & $10197 \pm 6494.5$ & 950 & 120000.0 \\
Eosinophils $\left(\mathbf{K} / \mathbf{m m}^{\mathbf{3}}\right)$ & $\mathbf{4 0 1}$ & $507.4 \pm 539.7$ & 1.0 & 5200.0 \\
Total Ig E $\left(\mathbf{K U}_{\mathbf{A}} / \mathbf{L}\right)$ & $\mathbf{4 0 1}$ & $89.2 \pm 244.6$ & 1.0 & 3010.0 \\
\hline
\end{tabular}

Supplemental Table 2. The eosinophil count, Total Ig E value and Eosinophil count / White blood cell count ratio for the presence of concomitant food allergy in preschool children with atopic dermatitis

\begin{tabular}{|c|c|c|c|c|}
\hline & & $\begin{array}{c}\text { Eosinophils count } \\
\left(\mathrm{K} / \mathrm{mm}^{\mathbf{3}}\right)\end{array}$ & $\begin{array}{c}\text { Total IgE } \\
(\mathrm{kU} / \mathrm{L})\end{array}$ & $\begin{array}{c}\text { Eosinophils count/WBC } \\
\text { ratio }\end{array}$ \\
\hline \multirow{4}{*}{$\begin{array}{c}1^{\text {st }} \text { study } \\
\text { subgroup }\end{array}$} & Cut Off & 525 & 13.85 & 0.0522 \\
\hline & AUC $(\% 95 \mathrm{CI}) / \mathrm{p}$ & $0.754(0.641-0.868) /<0.001$ & $0.657(0.419-0.716) / 0.334$ & $0.732(0.622-0.843) / 0.001$ \\
\hline & Sensitivity & $73.91(51.59-89.77)$ & $81.69(70.73-89.87)$ & $73.91(51.59-89.77)$ \\
\hline & Specificity & $63.64(52.69-73.63)$ & $37.16(30.73-43.94)$ & $65.91(55.03-75.68)$ \\
\hline \multirow{4}{*}{$<24$ month } & PPV & $34.69(26.89-43.42)$ & $29.74(26.70-32.97)$ & $36.17(27.96-45.28)$ \\
\hline & NPV & $90.32(82.17-94.98)$ & $86.17(78.73-91.30)$ & $90.62(82.70-95.13)$ \\
\hline & Accuracy & $65.77(56.16-74.51)$ & $48.10(42.21-54.02)$ & $67.57(58.03-76.15)$ \\
\hline & Cut Off & 355 & 26.85 & 0.0397 \\
\hline \multirow{3}{*}{$\begin{array}{l}2^{\text {nd }} \text { study } \\
\text { subgroup }\end{array}$} & AUC $(\% 95 \mathrm{CI}) / \mathrm{p}$ & $0.560(0.473-0.646) / 0.162$ & $0.616(0.541-0.691) / 0.006$ & $0.564(0.475-0.654) / 0.132$ \\
\hline & Sensitivity & $60.56(48.25-71.97)$ & $64.79(52.54-75.76)$ & $59.15(46.84-70.68)$ \\
\hline & Specificity & $50.46(43.63-57.28)$ & $53.21(46.35-59.98)$ & $57.34(50.48-63.99)$ \\
\hline \multirow{3}{*}{$\geq 24$ month } & PPV & $28.48(24.04-33.40)$ & $31.08(26.53-36.03)$ & $31.11(26.08-36.64)$ \\
\hline & NPV & $79.71(74.10-84.36)$ & $82.27(76.77-86.69)$ & $81.17(76.11-85.36)$ \\
\hline & Accuracy & $52.94(47.01-58.81)$ & $56.06(50.12-61.86)$ & $57.79(51.86-63.55)$ \\
\hline
\end{tabular}

AUC: Area under the curve, CI: Confident Interval, PPV: Positive Predictive Value, NPV: Negative Predictive Value. 


\section{Discussion}

Three significant results have been reached in predicting the presence of $\mathrm{FA}$ at the time of $\mathrm{AD}$ diagnosis in children. Firstly, gender, age, the age of onset of $\mathrm{AD}$, and $\mathrm{BEC}$ were determined as independent risk factors. Secondly, for patients, who started AD very early, time to start complementary feeding, kinship degree, and serum specific IgE milk positivity were independent risk factors, whereas, for patients with early-onset $\mathrm{AD}$, serum total $\mathrm{Ig} \mathrm{E}$ and specific IgE egg positivity were independent risk factors. Thirdly, in the evaluation of the presence of concomitant FA with quantitative data, a significant cut-off was determined for BEC and a ratio of $\mathrm{BEC} / \mathrm{WBC}$ for patients with very early $\mathrm{AD}$ onset age. Besides, a significant cut-off value for serum total IgE in patients with early-onset $\mathrm{AD}$ was identified.

Schloss et al. first reported the patients recovered from $\mathrm{AD}$ after the elimination of disturbing foods and demonstrated the relationship between FA and AD clinically (17). Then in many studies, food sensitivity was shown to be critical in the pathogenesis of $\mathrm{AD}$ (18). The prevalence of FA in $A D$ varies between $33 \%$ and $75 \%(19,20)$. This wide prevalence range may be the result of differences in the definition of FA in AD or referral of patients with severe AD to the tertiary centers $(6,7)$. This study was also performed in a tertiary care center, in which patients were directed to allergy and immunology clinics from Pediatrics and Dermatology departments. FA confirmed by OFC was detected in $23.6 \%$ of our AD patients simultaneously.

Early-type reaction was found in $19.3 \%$, latetype reaction in $5.6 \%$, and mixed type reaction in $23.4 \%$ of our patients, who underwent OFC test. AD was mostly accompanied by mixed food reactions. Werfel $\mathrm{T}$ et al. reported isolated eczematous responses in $10-25 \%$ and mixed type reactions in $40 \%$ of OFC tests in patients with $\mathrm{AD}(8)$. In this study, $9.7 \%$ of the SPTs showed the highest sensitivity to egg and $12.4 \%$ sensitivity to at least two nutrients. Similarly to us, Dharma et al. reported that allergen sensitization patterns in children with AD between 1-3 years of age were most susceptible to food, egg, milk, and peanut, respectively (21). In the OFC tests of our patients, the highest positivity was found against egg white, milk at the second frequency, and at least two foods at the third frequency. Likewise, in the literature, it is emphasized that more than $90 \%$ of the food allergies in children with $\mathrm{AD}$ are responsible for cow's milk, eggs, peanuts, soy, nuts, and fish.

In this study, only serum total $\operatorname{IgE}$ mean values were significantly different in preschool age children with $\mathrm{AD}$, according to the presence of concomitant FA. Serum total Ig E mean value of those with FA was more than twice as high as those without FA. In contrast, Beken et al. did not report any significant difference in serum total $\mathrm{Ig} \mathrm{E}$ value between the moderate-severe eczema group and mild-severe eczema among children ages 0-18 (22). We speculate that the difference might be associated with the type of FA reactions of children enrolled in their study.

There are few studies in identifying risk factors, in-vitro tests that can be used to predict the presence of FA in children with AD. Mailhol et al. identified age, $\mathrm{AD}$ onset age, and severity of $\mathrm{AD}$ as risk factors for FA that may accompany AD in children aged 018 years (23). In addition to these parameters, we had also identified gender, age, and age of onset of $\mathrm{AD}$, and $\mathrm{BEC}$ as independent risk factors for FA concurrent with AD. Accordingly, the increase in BEC in pre-school children with $\mathrm{AD}$ increases the risk of accompanying FA by 1001-fold. Noh et al. reported an $\mathrm{FA}$ rate of $70.8 \%$ in the $\mathrm{AD}$ group with high BEC in children with a mean age of $14-15$, who had eczematous AD. The majority of these cases were late-type eczematous FA (24).

The Filaggrin (FLG) mutation as a genetic susceptibility may have a significant role in the pathogenesis of AD. Patients with FLG mutations tend to have early-onset, severe, and persistent AD and are more likely to have asthma and allergic sensitivities $(25,26)$. FLG mutation was determined as an important risk factor for IgE-mediated peanut allergy and blamed epithelial barrier dysfunction in the pathogenesis (27). Similarly, we found that the increased degree of kinship in infants, whose atopic symptoms started very early, increases the risk of FA.

Spergel et al. aimed to determine serum specific Ig E cut off value of 6 nutrients (milk, egg, peanut, soybean, wheat flour, and seafood) in predicting FA in 3-18 months children with mild to severe AD. They concluded with the useless of using foodspecific $\operatorname{IgE}$ to predict the development of FA clinically (28). However, we found only serum milk specific $\operatorname{IgE}$ and total $\operatorname{IgE}$ as an independent risk factor for the development of FA for patients, who had very early-onset AD.

High blood eosinophil counts were reported by Noh et al. as a predictor of anticipating FA in children with $\mathrm{AD}$ with a mean age of $14.3 \pm 14.7$ years. They recommended only elimination diet in patients with eczematoid $\mathrm{AD}$ with high eosinophilia $[>5 \%, \quad$ mean $\pm \mathrm{SD}=8.9 \pm 5.0 \%, \quad$ TEC $=10.9+$ (7.15XEOS\%)] (24). Although we determined a significant cut-off value of BEC and BEC/WBCs ratio in predicting $\mathrm{FA}$ in children, who had very early-onset $\mathrm{AD}$, this was not the case for children, who had early-onset AD.

To date, elevated serum total IgE levels have not seen as a non-specific marker affecting the interpretation of food-specific IgE in patients with allergic disorders. Therefore, it is reasonable not to recommend measuring total $\operatorname{IgE}$ levels in the evaluation and treatment of FA (29). However, 
Federly et al. reported that there was a significant and parallel relationship between serum total $\mathrm{IgE}$ and food-specific IgE levels, in particular with egg, milk, peanut, and soy (30). In a way of supporting them, we found a significant cut off value for serum total IgE value in predicting FA in children with early-onset $\mathrm{AD}$ with a sensitivity and specificity of $65 \%$ and $53 \%$, respectively. The correct use of serum total $\mathrm{IgE}$ in $\mathrm{FA}$ prediction in children with $\mathrm{AD}$ deserves further studies.

The limitations of this study were its retrospective design and the lack of food-specific IgE parameters in our patient group due to the limited laboratory facilities. Concomitant FA reactions in our children with $\mathrm{AD}$ differed according to the OFC test results, and the number of patients for these three types of food reactions was relatively low. Therefore, studies with a higher number of patients are needed for all three types of nutritional reactions in $\mathrm{AD}$.

Consequently, approximately one-third of children with AD have food allergies. We suggest that the parameters that will help to predict the presence of $\mathrm{FA}$ in $\mathrm{AD}$ patients will not only determine the accompanying FA but will also prevent unnecessary food elimination in these children, which is highly essential in their age of growth

\section{Acknowledgment}

My special thanks to Naci Murat (Assoc. Prof.) for assistance in performing the statistical analysis of the research data. I am also grateful to Ozlem Ezgingil (Nurse), who served with love for our patients.

Ethics Committee Approval: The study was approved by University of Health Sciences, Gulhane Research and Training University Hospital's Ethical Committee (Project/Decision no: 19/412; Meeting no: 2019/18).

\section{References}

1. Roduit C, Frei R, Depner M, et al. Phenotypes of Atopic Dermatitis Depending on the Timing of Onset and Progression in Childhood. JAMA Pediatr. 2017;1;171: 65562.

2. Du Toit G, Santos A, Roberts G, et al. The diagnosis of IgEmediated food allergy in childhood. Pediatr Allergy Immunol. 2009;20:309-19.

3. Mastrorilli C, Caffarelli C, Hoffmann-Sommergruber K. Food allergy and atopic dermatitis: Prediction, progression, and prevention. Pediatr Allergy Immunol. 2017;28:831-40.

4. Portelli MA, Hodge E, Sayers I. Genetic risk factors for the development of allergic disease identified by genome-wide association. Clin Exp Allergy.2015;45:21-31.

5. Lockett GA, Huoman J, Holloway JW. Does allergy begin in utero? Pediatr Allergy Immunol. 2015;26:394-2.

6. Rowlands D, Tofte SJ, Hanifin JM. Does food allergy cause atopic dermatitis? Food challenge testing to dissociate eczematous from immediate reactions. Dermatol Ther. 2006;19:97-3

7. Suh KY. Food allergy and atopic dermatitis: separating fact from fiction. Semin Cutan Med Surg. 2010;29:72-8.
8. 8.Werfel T, Ballmer-Weber B, Eigenmann PA, et al. Eczematous reactions to food in atopic eczema: position paper of the EAACI and GA2LEN. Allergy. 2007;62:723-28.

9. Gray CL, Levin ME, Zar HJ, Potter PC, et al. Food allergy in South African children with atopic dermatitis. Pediatr Allergy Immunol. $2014 ; 25: 572-79$.

10. Burks AW, James JM, Hiegel A, et al. Atopic dermatitis and food hypersensitivity reactions. J Pediatr. 1998;132:132-36.

11. Sampson HA, McCaskill CC. Food hypersensitivity and atopic dermatitis: evaluation of 113 patients. J Pediatr. 1985;107:669-75.

12. Eigenmann PA, Calza AM. Diagnosis of IgE-mediated food allergy among Swiss children with atopic dermatitis. Pediatr Allergy Immunol. 2000;11:95-0.

13. García C, El-Qutob D, Martorell A, et al. Sensitization in early age to food allergens in children with atopic dermatitis. Allergol Immunopathol (Madr). 2007;35:15-0.

14. Bousquet J, Heinzerling L, Bachert C, et al. Global Allergy and Asthma European Network; Allergic Rhinitis and its Impact on Asthma. Practical guide to skin prick tests in allergy to aeroallergens. Allergy. 2012;67:18-4

15. Nowak-Wegrzyn A, Assa'ad AH, Bahna SL, et al. Adverse Reactions to Food Committee of American Academy of Allergy, Asthma \&Immunology. Work Group report: oral food challenge testing. J Allergy Clin Immunol. 2009; $123: 365-83$.

16. 16.Bieber T, D'Erme AM, Akdis CA, et al. Clinical phenotypes and endophenotypes of atopic dermatitis: Where are we, and where should we go? J Allergy Clin Immunol. 2017;139:58-64

17. Schloss OM. Allergy to common foods. Trans Am Pediatr Soc. $1915 ; 27: 62-8$

18. Greenhawt M. The role of food allergy in atopic dermatitis. Allergy Asthma Proc. 2010;31:392-97.

19. 1Rancé F. Food allergy in children suffering from atopic eczema. Pediatr Allergy Immunol. 2008;19:279-84

20. Uenishi T, Sugiura H, Tanaka T, et al. Role of foods in irregular aggravation of skin lesions in children with atopic dermatitis. J Dermatol. 2008;35:407-12.

21. Dharma C, Lefebvre DL, Tran MM, et al. Patterns of allergic sensitization and atopic dermatitis from 1 to 3 years: Effects on allergic diseases. Clin Exp Allergy. 2018;48:48-59.

22. Beken B, Celik V, Gokmirza Ozdemir P, et al. Food Sensitization and Food Allergy in Atopic Dermatitis. Osmangazi J Med. 2019;41:405-12.

23. Mailhol C, Giordano-Labadie F, Lauwers-Cances V, et al. Point prevalence and risk factors for food allergy in a cohort of 386 children with atopic dermatitis attending a multidisciplinary dermatology/paediatric allergy clinic. Eur J Dermatol. 2014;24:63-9.

24. Noh G, Jin H, Lee J, et al.Eosinophilia as a predictor of food allergy in atopic dermatitis. Allergy Asthma Proc. 2010;31:18-24.

25. Henderson J, Northstone K, Lee SP, et al. The burden of disease associated with filaggrin mutations: a populationbased, longitudinal birth cohort study. J Allergy Clin Immunol. 2008;121:872-7.

26. Barker JN, Palmer CN, Zhao Y, et al. Null mutations in the filaggrin gene (FLG) determine major susceptibility to earlyonset atopic dermatitis that persists into adulthood. J Invest Dermatol. 2007; 127:564-67.

27. Brown SJ, Asai Y, Cordell HJ, et al. Loss-of-function variants in the filaggrin gene are a significant risk factor for peanut allergy. J Allergy Clin Immunol. 2011;127:661-67.

28. Spergel JM, Boguniewicz M, Schneider L, et al. Food Allergy in Infants With Atopic Dermatitis: Limitations of Food-Specific IgE Measurements. Pediatrics. 2015;136:1530-8.

29. Burks AW, Jones SM, Boyce JA, et al. NIAID-sponsored 2010 guidelines for managing food allergy: applications in the pediatric population. Pediatrics. 2011;128:955-65.

30. Federly TJ, Jones BL, Dai H, et al. Interpretation of food specific immunoglobulin E levels in the context of total $\mathrm{IgE}$. Ann Allergy Asthma Immunol. 2013;111:20-4. 